Vol.1, No.1, Issue.1, pp.20-29, 2019

Available online at: https://tljbm.org/jurnal/index.php/tljbm

\title{
Development of Monitoring System for Scholar Data in the Ministry of Health Timor-Leste
}

\author{
Jorge B. da Cunha ${ }^{1}$, Edio da Costa $^{1}$, Remyanus Tunti ${ }^{1}$, Melny E. Timu ${ }^{1}$ \\ Email: ediocosta73@gmail.com, remyanustunty83@gmail.com, melnyitimu@yahoo.com \\ School of Engineering and Science, Dili Institute of Technology
}

\begin{abstract}
The objective of this study is to develop the monitoring system of scholarship data in the Ministry of Health Timor-Leste to facilitate monitoring activities of the Timorese students within the country or abroad. And also, how to know when the scholars complete their studies and the cost which has been spent each year. The methods used to develop the system are Waterfall Modeling, Data Flow Diagram (DFD) and Entity Relationship Diagram (ERD). The programming language used to build the system are Hypertext Preprocessor (PHP) 5.6.2, My Structured Query Language (MySQL) 5.1.37, and Xamp 3.2.2. The observation and interview are used to collect the data from the Ministry of Health Timor-Leste. The result of the system is able to monitor the scholars who will graduate every year, and also be able to know about the total of scholars studying in every area. The system is also able to monitor the payment data every scholar and the operational cost, producing reports such as field of study in each student, and payment detail each student during the process of the study.
\end{abstract}

Keywords: Ministry of Health Timor-Leste, monitoring system, DFD, ERD, PHP, MySQL and Xampp.

\section{Introduction}

The scholarship has become government program which is through the Ministry of Health Timor-Leste in partnership with other countries via Embassy of Cuba, China, Indonesia, Thailand, New Zealand, Australia including Community of Portuguese speaking Countries to offer and support Timorese people to continue their study and increasing capacity and ability to contribute for the development of Timor-Leste in the future.

Information System manages data based on the web which has been implemented in various study cases such as scholarship monitoring system in Diponegoro University (Shodiq at.al., 2013), analysis and development monitoring system Bidikmisi in University Negri Yogyakarta (Setiawan, 2015), and analysis monitoring scholarship in Jambi (Gusmarni, 2017). The results of those research show that the information system monitoring data scholar is based on the web which is possible to be implemented to facilitate the Human Resource National Department in order to control the scholars who study within the country or overseas.

Based on the interview with Mrs. Auxiliadora Correia in Human Resource Planning Department, Ministry of Health Timor-Leste that every year there are almost twenty domestic and foreign scholars who continue their study. Those numbers are depending on the program which is given by the government to provide scholarships for Timorese people to study in the health area. We also have partners such as Thailand International Cooperation Agency (TICA), the Korean International Cooperation Agency (KOICA) and others which always provide scholarship for the Timorese people every year.

The data scholar increases every year, it is difficult for the Human Resource Planning Department, Ministry of Health Timor-Leste to control for studying process every scholar in every country. And it is difficult to make the structure report because it has incomplete data, do not know the details about the budget issued for each scholar because there is no good data management causing a lot of lost data. These problems arise because there is no system that can accommodate all scholar data.

Therefore, the objective of this study is to develop the monitoring system scholarship data in the Ministry of Health Timor-Leste to facilitate monitoring activities for Timorese domestic and foreign students. And also, how to know when scholars complete their studies and the cost which has been spent for the scholars each year.

\section{Literature Review}

\subsection{Information System}

The information system is a system composed of people and computers that processes or interprets information (Jessup et. al., 2008; Bulgacs and Simon, 2013). The term is also sometimes used in more restricted senses to refer to only the software used to run a computerized database or to refer to only a computer system. Any specific information system aims to support operations, management and decision-making (Alter, 2013). The information system consist of three components such as input, process, and output (Abdul, 2003). These components (Laudon \& Laudon, 2010) work together to collect, process, store and disseminate information to support decision making, coordination, control, problem analysis and visualization within an organization. The use of information systems is growing as an example of organizations using information systems to process transactions, reduce costs and generate revenue as one of their products or services, another example is the Bank has now used the information system to process customer checks and make various account statements newspapers and transactions that occur (Jogyanto 2012).

Monitoring information system is a process to collect and analyze the information based on the indicators that have been determined systematically and continuously about an activity or program so that action can be taken as an attempt to perfect 
Vol.1, No.1, Issue.1, pp.20-30, 2019

Available online at: https://tljbm.org/jurnal/index.php/tljbm

the next activity or program (Hafidz et.al., 2017 ). The Monitoring system is the process of controlling routine data collection and measuring progress on program objects or systems that can control activities in storing data, especially in controlling the academic achievement and activities of the student (Hermansyah and Paulina, 2013).

\subsection{Waterfall Method}

The waterfall method is a classic life cycle model, which implies a systematic and sequential approach to software development, which starts with the specification of user needs and continues through the stages of planning (planning), modeling (modeling), construction (construction), as well as the transfer of the system / software to the users which ends with ongoing support for the complete software produced (Pressman et.al., 2012; Casteren, 2017).

\subsection{Tools}

Xampp is free software, which supports many operating systems, and is a compilation of several programs (Palit et.al., 2015). This program is available under the GNU General Public License and is free, an easy-to-use web server that can serve a dynamic web page, and can be run on many operating systems, such as Windows, Linux, Mac OS, and Solaris (Walia and Gill, 2014; Ayu and Permatasari, 2018).

\subsection{Black Box Testing}

The Black Box Testing is a method of software testing that examines the functionality of an application without peering into its internal structures or workings. This method of test can be applied virtually to every level of software testing: unit, integration, system and acceptance (Jerry et. Al., 2003). The testing design chooses valid and invalid inputs and determines the correct output, without having to know the internal structure of the tested (Simanjuntak, 2010). This method can be applied at all levels of software testing such as unit, functional, integration, system and user acceptance. The Black Box Testing is conducted to find errors in several categories, namely: (1) Missing or incorrect functions; (2) Interface design errors, (3) Errors in data structures or external database access; (4) Performance error; and (5) Initialization and termination errors (Febiharsa et.al., 2018).

\section{Research Methods}

The data are used to develop the system in this study obtained from the Department of Human Resource Planning, Ministry of Health Timor-Leste. Figure 3.1 such a system architecture to develop information system manages scholarship data. This system consists of Administrator such as the entity which has full access to manage the system. Furthermore, the circulation data about scholarship in the Ministry of Health also access the report to make a decision. The users are such the students who are able to access the system to get the information about the money and able to input their value to the system.

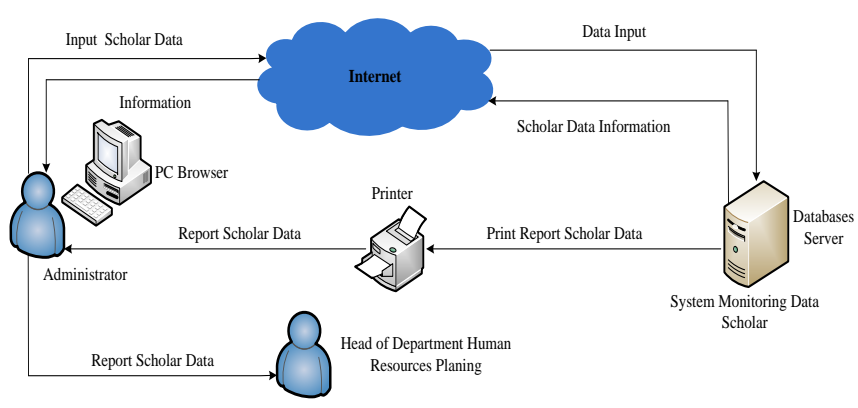

Figure 3.1 Architecture System

Figure 3.2 describes all process of the system to connect the system with all entities. The system consists of admin as the entity that has the highest permissions, department heads have the competence to access information in the system, especially information about scholars and reports used for decision making. The process in this system consists of input data such as step which used to input all data that by the entity Administrator, that will be recorded in master table (1.0), monitoring data is the activity system which will process all data that with the resource from processing (2.0) and the last will making report (3.0) to inform to the entity of Chef Department Human Resource Planning Department to use for decision making. 
Vol.1, No.1, Issue.1, pp.20-29, 2019

Available online at: https://tljbm.org/jurnal/index.php/tljbm

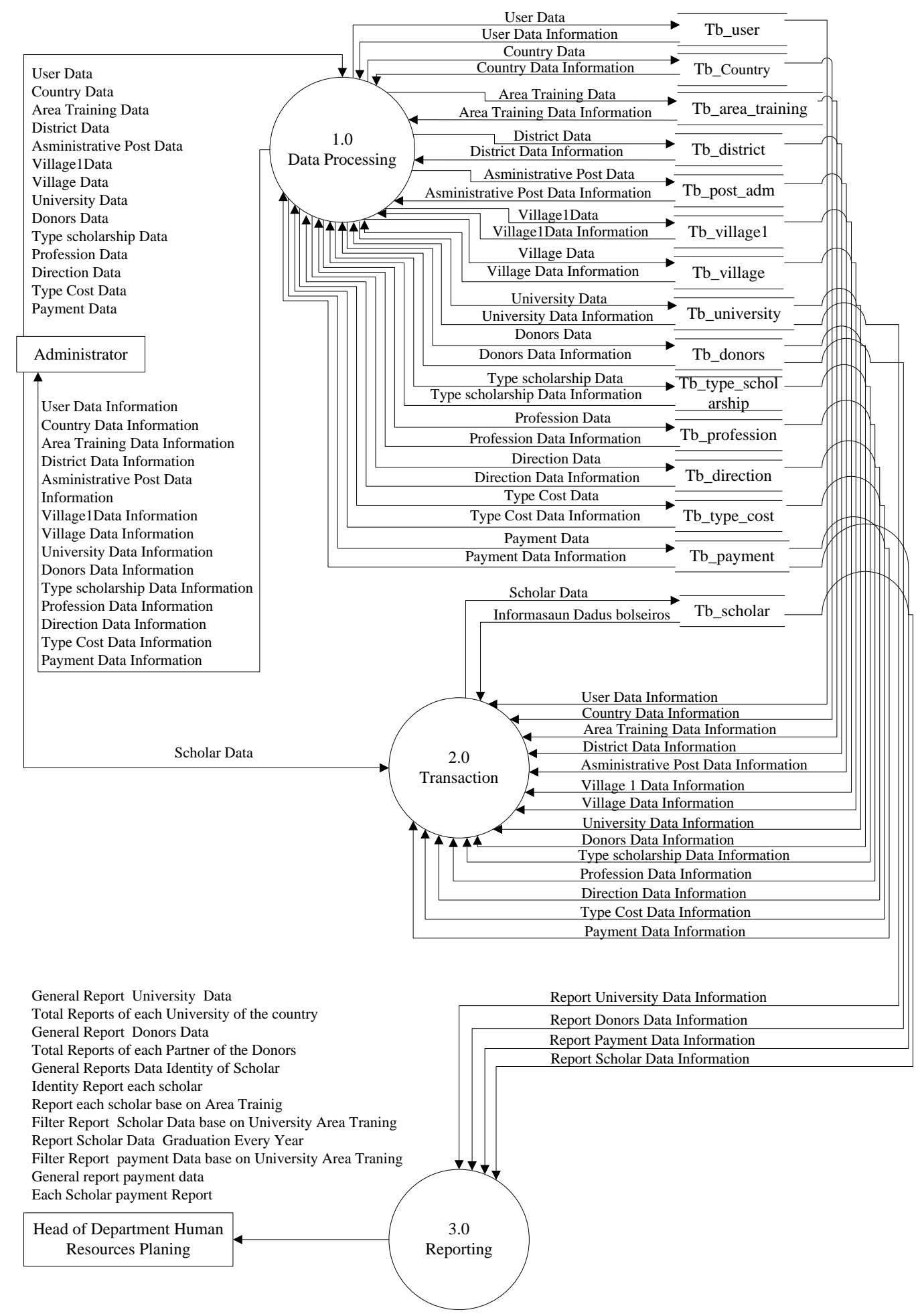

Figure 3.2 Diagram of Monitoring System

Entity Relationship Diagram (ERD) as a model that describes the relationships between entities in the database. Figure 3.3 such as a stepping which describes about relation within entity that includes the system. Example; the relationship between entity scholar and training Area is one-to-one that in each scholar is able to choose one training area. And also the relationship between University and Country is manyto-many that in many universities in each country and entity one university in many training areas. 
Vol.1, No.1, Issue.1, pp.20-30, 2019

Available online at: https://tljbm.org/jurnal/index.php/tljbm

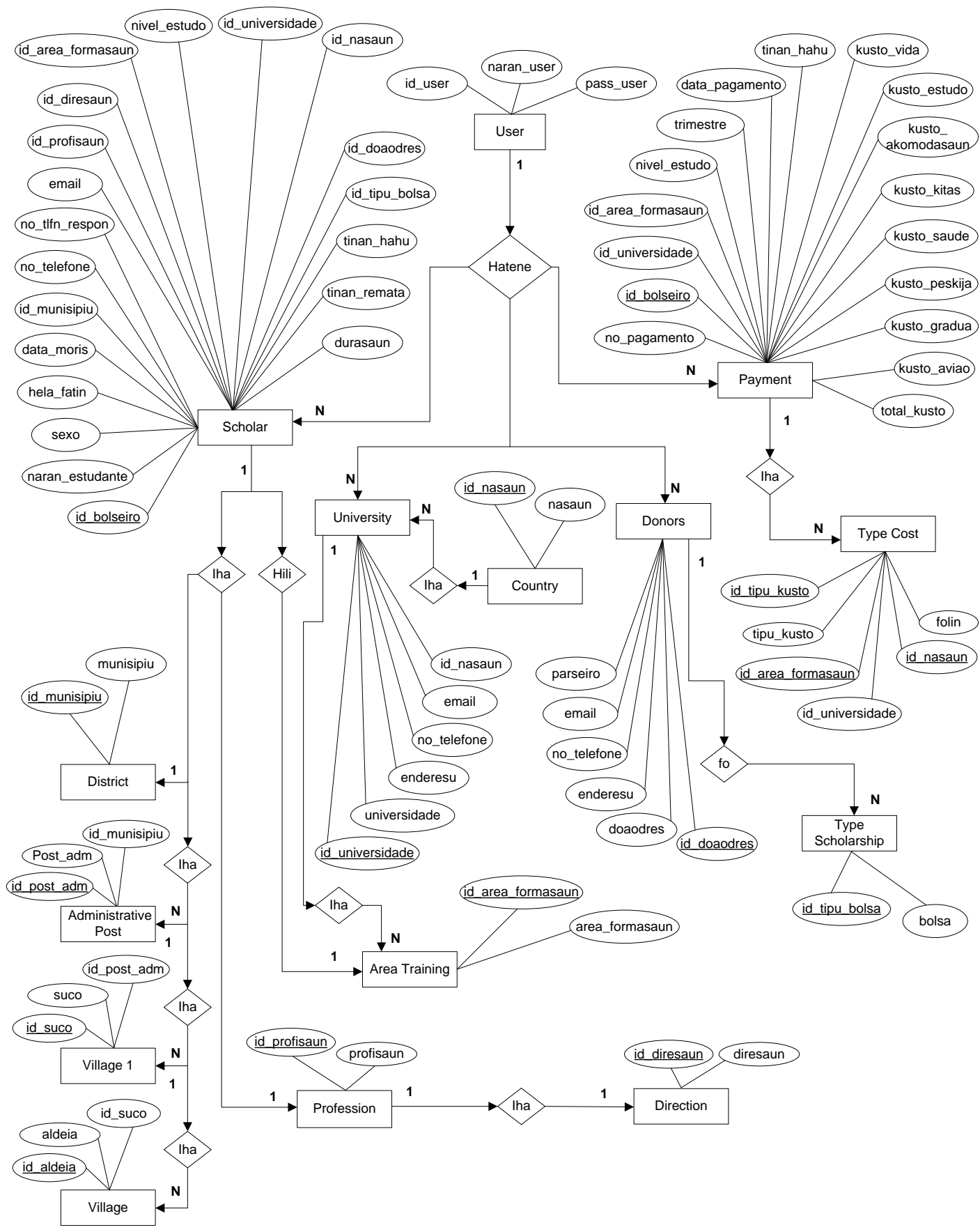

Figure 3.3 Entity Relation Diagram (ERD)

Figure 3.4 describes relations between the table in the information system monitoring scholar in the Ministry of Health Timor-Leste. The system consists of 15 tables, three tables transaction such as tb_scholar, tb_payment, and tb_type_cost. And twelve table master. 
Vol.1, No.1, Issue.1, pp.20-29, 2019

Available online at: https://tljbm.org/jurnal/index.php/tljbm

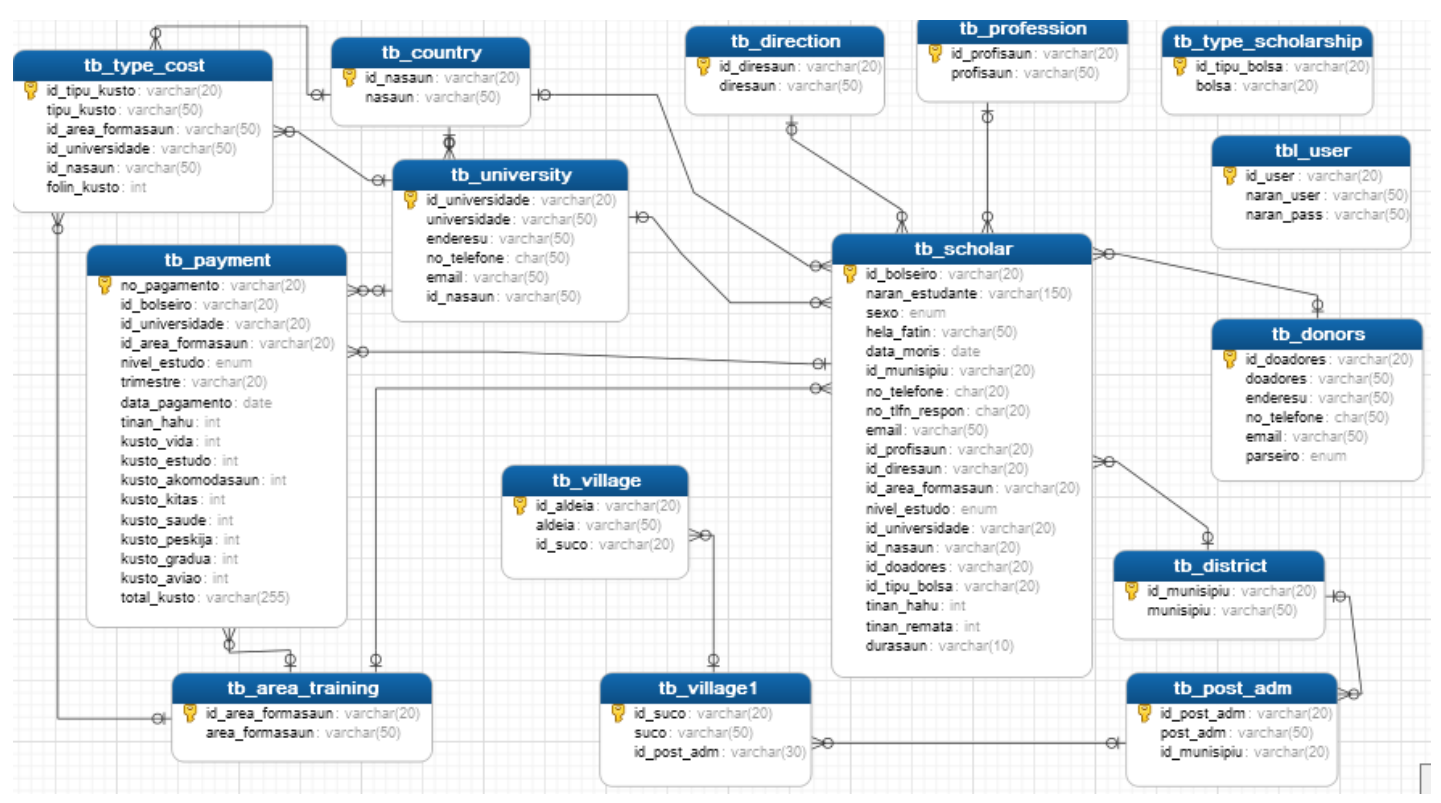

Figure 3.4 Relation of Monitoring System

The Method of Development System in this research is a Waterfall. The purpose of using this method is because it has a detail process and structure such as analysis, system design, testing system, implementation and maintenance (Pressman, 2015). The proposed need to develop a monitoring system are:

- Create a system based on database "db_bolseiru_ms"

- System validation such as $\log$ in with three users are administrator, chief of department, and the employees

- The feature for searching data

- The system can monitor students contract, the cost which purchases for the studying process, and also to monitor their studying process via their results of study.

- Produce report based on data which has been processed from the system in anytime.

\section{Result}

Before going to Dashboard Menu, First the system will make validation to user by login such as Username and Password. Figure 4.1 is a Dashboard information system, monitoring data fellow which consist of Fellow, University, Donors and Payment.

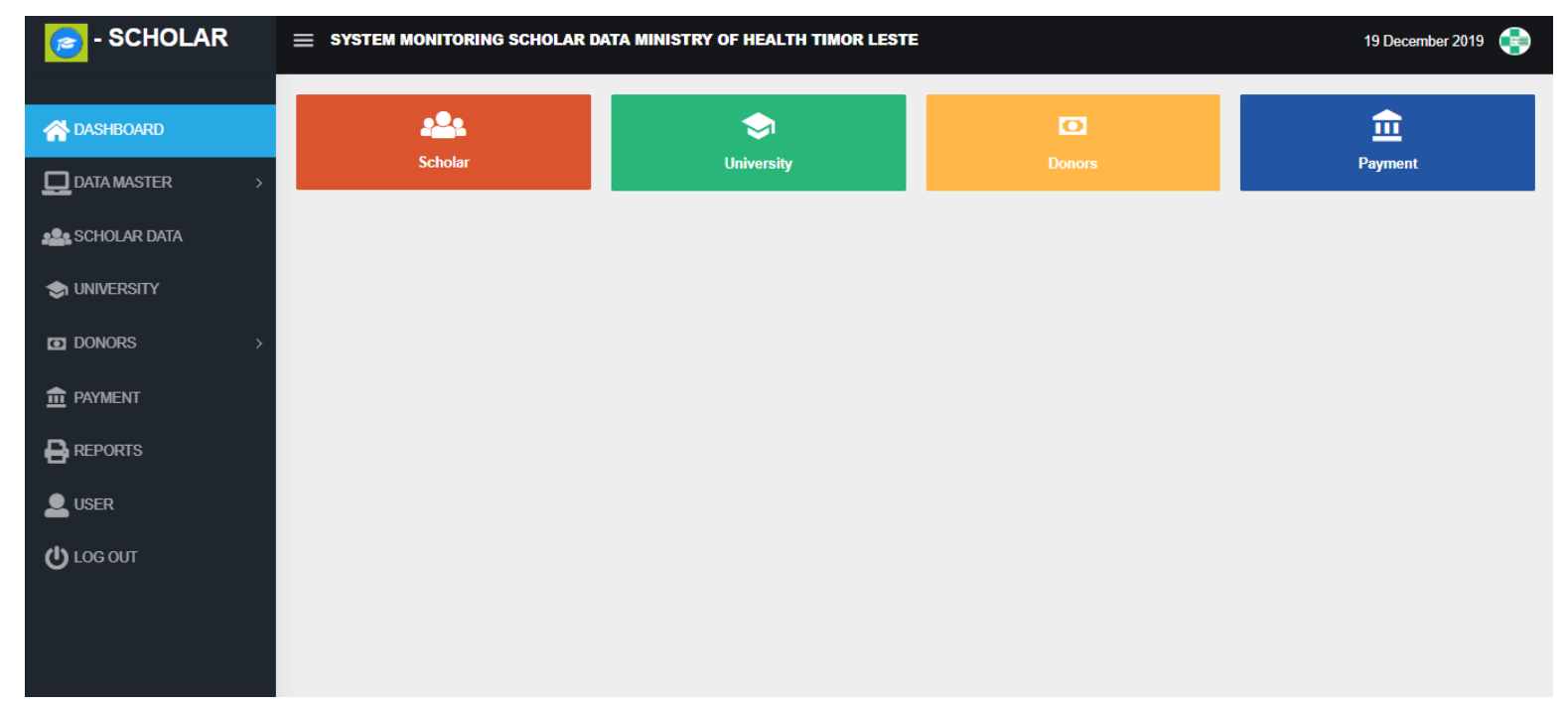

Figure 4.1 Dashboard Menu 
Vol.1, No.1, Issue.1, pp.20-30, 2019

Available online at: https://tljbm.org/jurnal/index.php/tljbm

Master Menu consists of four sub-menu such as, District, Training Area, Country and Profession. The whole information which has relation with four sub-menu will directly input from Admin in Human Resource National Direction, Ministry of
Health Timor-Leste. Figure 4.2 is an out coming data interface which is consist of data District, Training Area, Country and Profession.
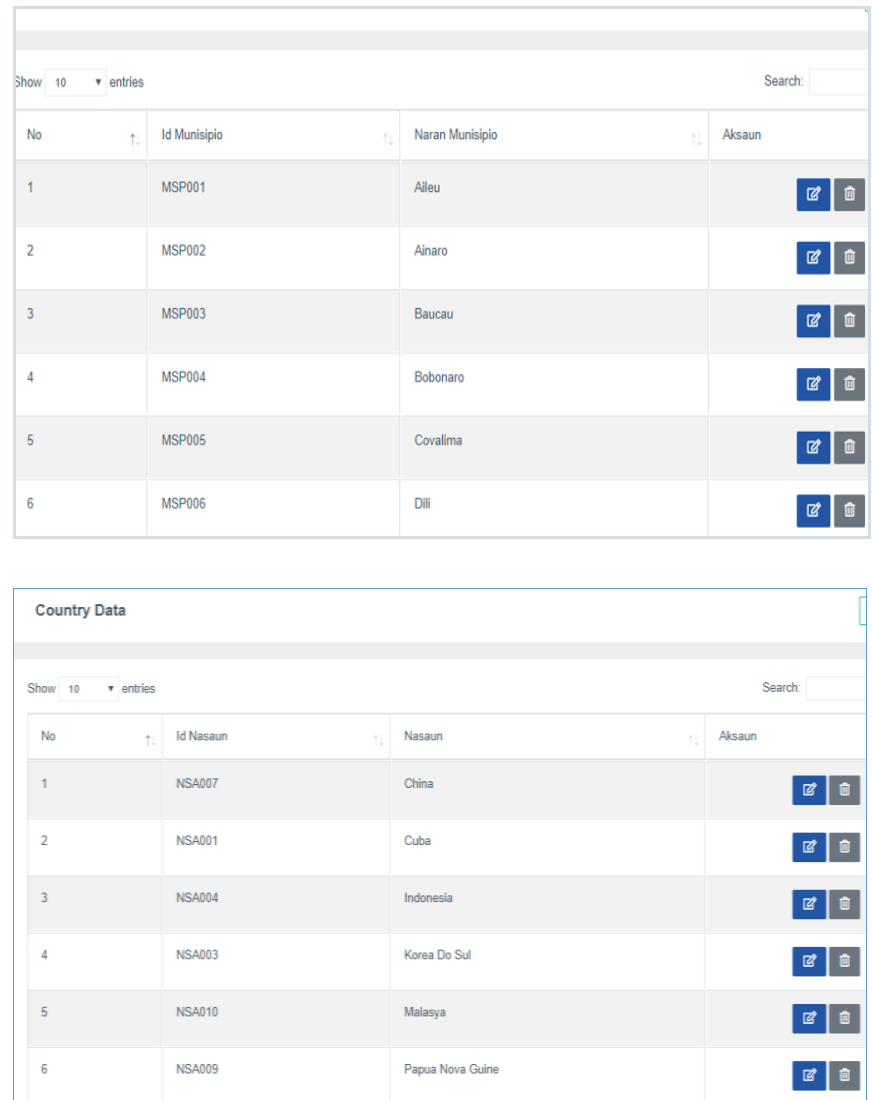
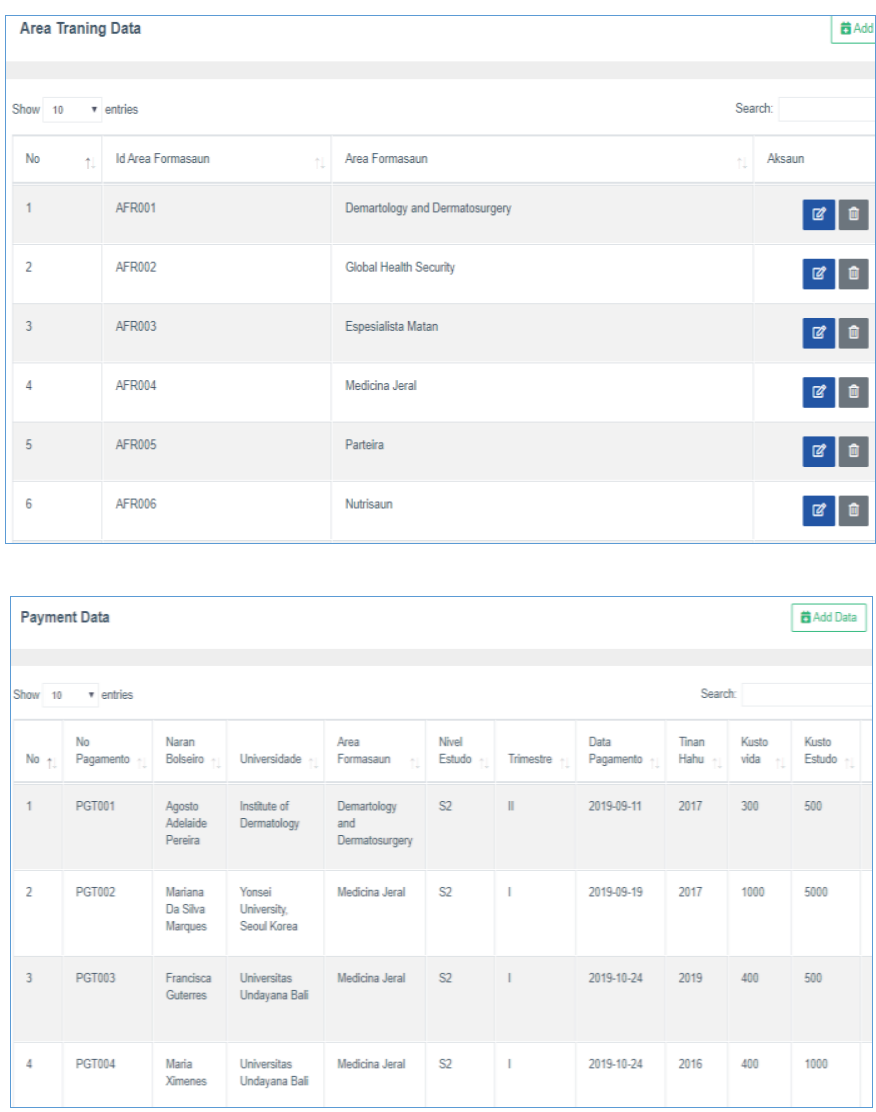

Figure 4.2 Inrerface Data District, Area of Concetration, Country and Profession

Figure 4.3 Shows the form interface which is used to input data scholar. This form is used to save and manage data such as, input data, edit data, and delete data. User will be able to get information about the identity of scholar, training area, studying in which country and university.

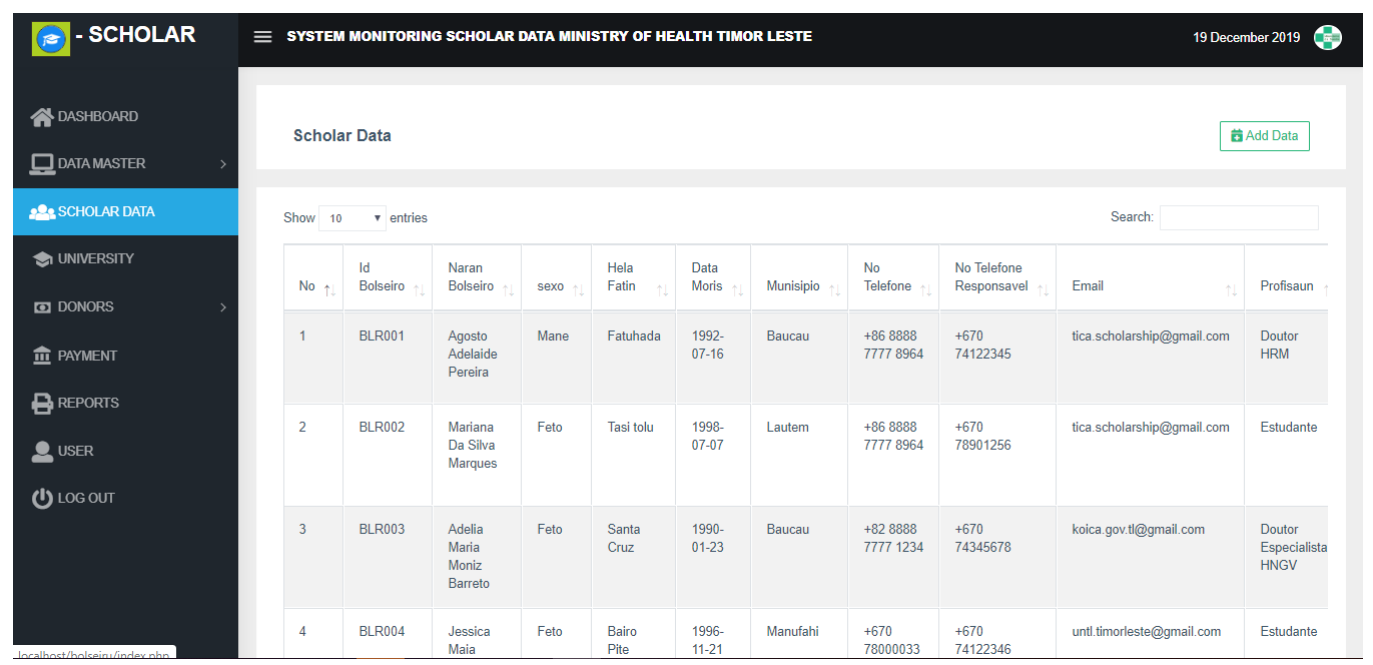

Figure 4.3 Data of Scholar 
The result of development system also produces the report which consists of general university data report, university data report in each country, general data donors report, donors report in each partner, the data filter of scholar based on the training area and university in each countries. 6) report of scholar's general data identity 7) report of each scholar's iden- tity 8) report of training area for each scholar 9) data graduation fellow report in each year 10) data filter payment base on training area and university 11)data filter payment report in each fellow 12) general data payment report. Figure 4.4 such a interface facility which used to produce report.

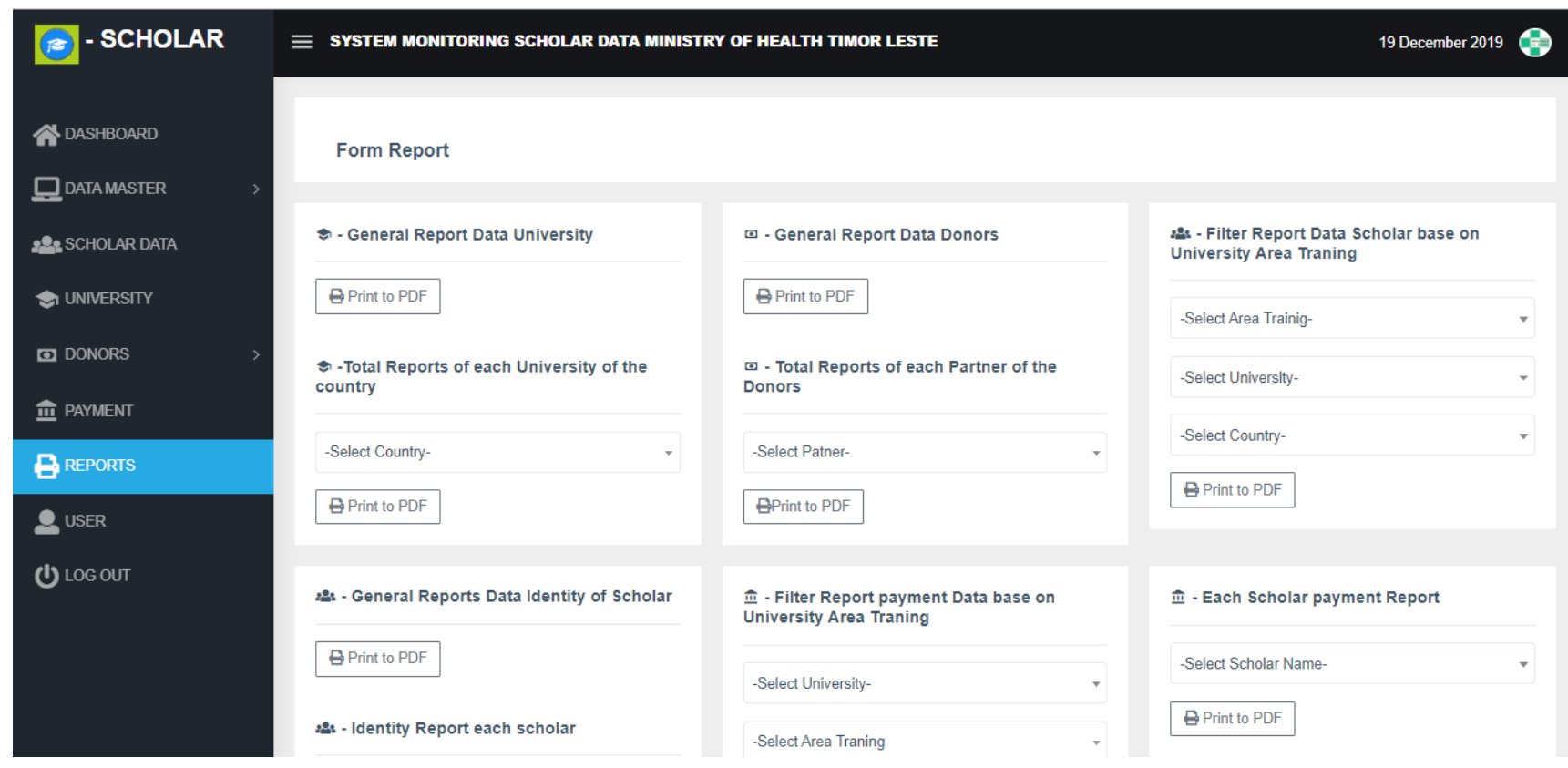

Figure 4.4 Report Printing Form

Figure 4.5 is the outcome of report which is produced by the system. The produced report consists of university report in each country where the scholars studying at.

\begin{tabular}{|l} 
REPBULIC DEMOCRATIC OF TIMOR-LESTE \\
MINISTRY OF HEALTH \\
National Direction Human Resources
\end{tabular}

Figure 4.5 University Report From Each Country Where Scholars Pursue Their Studies. 
Figure 4.6 is the result of report which is produced by information system which has been developed. It is producing information such as data filter training area, university and country. All infor- mation which have been produced by the system is able to help the human Resource Nation Direction to give Decision.

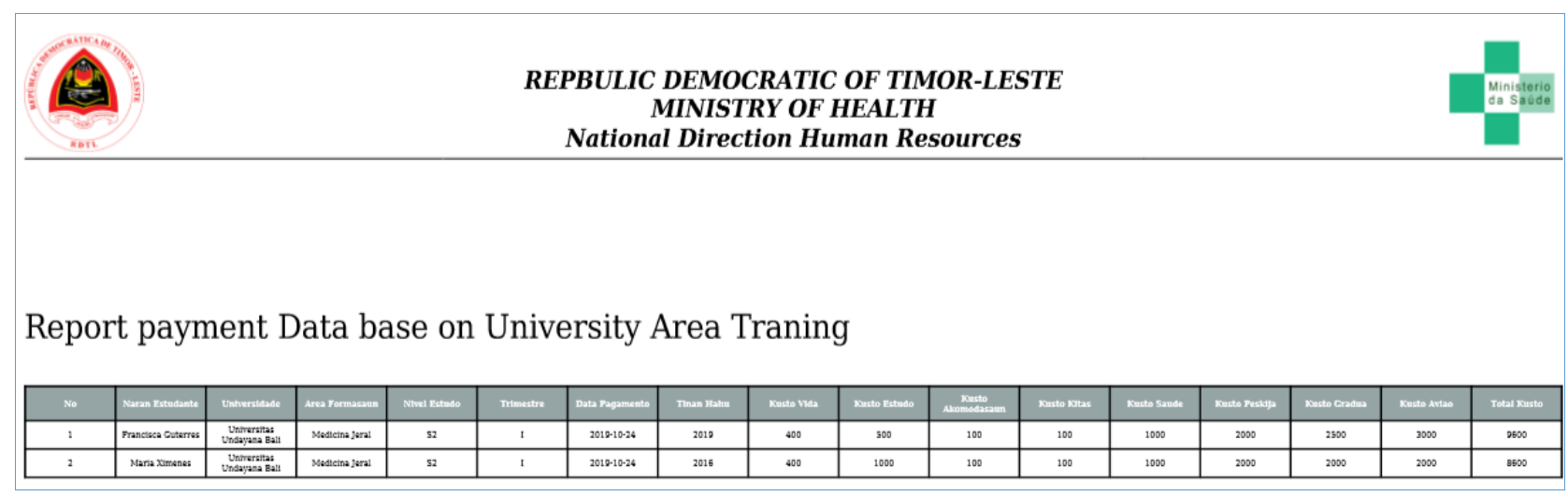

Figure 4.6 Scholars Data Filter Report of training area at Universities and Countries.

\section{Evaluation System}

Test of evaluation system in this research used a black box techniques such as :

- Testing the function of system analysis which is designed with DFD

- The truth of the software being tested is only seen based on the output (output) generated from the data or the conditions of the input provided for the existing function without seeing the process of how to get the output. From the output produced, the ability of the program to meet the needs of users can be measured as well as its errors can be identified.

- The test results are declared successful if when given input according to the test plan the system has been able to deliver the output (appearance and function) as expected.

Table 5.1 Black Box Result Testing

\begin{tabular}{|c|c|c|}
\hline Level of Test & Sub Test & Result \\
\hline \multirow{2}{*}{ Authentication/ Login } & Validation of Input & Success \\
\hline & Account Validation (redirect, menu according to access rights) & Success \\
\hline \multirow{6}{*}{ Dashboard Menu } & Display menu data master & Success \\
\hline & Data recapitulation of concentration area (add, delete, edit, and update) & Success \\
\hline & Data recapitulation of university (add, delete, edit, and update) & Success \\
\hline & Data recapitulation of scholar (add, delete, edit, and update) & Success \\
\hline & Data recapitulation of country (add, delete, edit, and update) & Success \\
\hline & Data recapitulation of donors (add, delete, edit, and update) & Success \\
\hline \multirow[b]{2}{*}{$\begin{array}{l}\text { Scholar Data Monitor- } \\
\text { ing }\end{array}$} & Display information about financial status for each scholar & Success \\
\hline & $\begin{array}{l}\text { Display information about the status of each scholar on their study in } \\
\text { every University }\end{array}$ & Success \\
\hline Scholar Data Payment & Admits information about payment for each scholar in every trimester. & Success \\
\hline \multirow{10}{*}{ Report } & Report of University Data in every country & Success \\
\hline & General report Data of donors & Success \\
\hline & Donors' Report for each partner & Success \\
\hline & Scholar's Data Filter according to area of training, university and country & Success \\
\hline & General Report Data of Scholars' identity & Success \\
\hline & Report of Identity for each scholar & Success \\
\hline & Report of each scholar according to area of training & Success \\
\hline & Report of graduated scholars' data every year & Success \\
\hline & Filter Data Report of payment for each scholar & Success \\
\hline & General Report Data Payment & Success \\
\hline
\end{tabular}


Vol.1, No.1, Issue.1, pp.20-29, 2019

Available online at: https://tljbm.org/jurnal/index.php/tljbm

Table 5.2 showed, the functions contained in the Information monitoring system of fellow chest have been running well and according to the design that has been made. That is the main function on the system has been used successfully and does not experience errors, if there are errors or warnings from the system, this is caused by users who do not provide input correctly. Functionally, this system can produce outputs that are as expected by the users.
The weakness in this system is the process of managing the payment status which is still done manually, namely transfers through the Bank by the ministry to each fellow, cannot be done automatically by the system when there is a delay in payment that exceeds the terms and conditions. In addition the system also cannot display notifications of late payments automatically

Table 5.2 Evaluation System

\begin{tabular}{|c|l|l|}
\hline \multicolumn{2}{|c}{ No } & \multicolumn{2}{c|}{ Result } \\
\hline 1 & Login Proses & Function goes well \\
\hline 2 & Add Data Proses & All Function go well \\
\hline 3 & The process of printing the payment timeline & All Function go well \\
\hline 4 & The tracking process of data payment every semester & All Function go well \\
\hline 5 & The monitoring process of payment status & All Function go well \\
\hline 6 & The process of knowing payment details & All Function go well \\
\hline 7 & $\begin{array}{l}\text { The process of printing report every student in each se- } \\
\text { mester }\end{array}$ & All Function go well \\
\hline 8 & $\begin{array}{l}\text { The process of managing payment status } \\
9\end{array}$ & $\begin{array}{l}\text { Payment data update process } \\
\text { The functions run according to the design, but the limi- } \\
\text { tation in the status changes are still done manually not } \\
\text { automatically when there is a delay }\end{array}$ \\
\hline 10 & Payment data filters based on the school and University & $\begin{array}{l}\text { The function runs according to the design, the lack of } \\
\text { notification of delay that cannot run according to the } \\
\text { design }\end{array}$ \\
\hline 11 & The report printing process of general data payment & All Function go well \\
\hline 12 & $\begin{array}{l}\text { The process of printing Report sources of funds based on } \\
\text { students }\end{array}$ & All Function go well \\
\hline
\end{tabular}

\section{Conclusion and Recommendation}

The result of this research has developed a prototype application monitoring system data fro scholars at Ministry of Health Timor-Leste based on Web in Human Resource Planning Department. The developed system is able to monitor scholars who have got scholarship from Ministry of Health in overseas or domestic including names of universities or institutions, also to know about what special areas do the scholars study. This system is also able to save data tuition fees, scholars' operational cost and also provides information about what price must be spent by the scholars to conclude their studies based on those who have concluded their studies at university. Easy to make report is the system which is developed with facilities to produce report such as: graduation report in each year, and general payment report for each scholar.

The expectation for researcher is to be able to implement software technique test which is a variation to get an accurate output from the result. In developing the prototype of this information system, it has not yet paid attention to the issue of data security (security), so for that further research can be supplemented by its data security system.

\section{Reference}

Alter, S (2013). Work System Theory: Overview of Core Concepts, Extensions, and Challenges for the Future" Journal of the Association for Information Systems. Vol. 14 No. 2 p. $72-121$.

Ayu F. and Permatasari N. (2018). Perancangan Sistem Informasi Pengolahan Data Praktek Kerja Lapangan (PKL) Pada Devisi Humas PT. Pegadaian. Volume 2, No.2.

Bulgacs, Simon (2013). "The first phase of creating a standardised international innovative technological implementation framework/Software application".International Journal of Business and Systems Research.

Casteren W.V. (2017). The Waterfall Model and the Agile Methodologies : A comparison by project characteristics - short.

Guswarni N. and Siahaan K. (2017). Analisis Dan Perancangan Sistem Monitoring Informasi Beasiswa Bidikmisi Di Lain Sultan Thaha Saifuddin Jambi. Jurnal Manajemen Sistem Informasi. Vol.2, No.2. 
Vol.1, No.1, Issue.1, pp.20-30, 2019

Available online at: https://tljbm.org/jurnal/index.php/tljbm

Hermansyah dan Pauline R.S., (2013. )Sistem Informasi Monitoring Prestasi Akademik dan Aktifitas Siswa Sekolah Dasar Berbasis Web, ISSN: 2088-1762 Vol. 3, No. 2, Tanggerang: Jurnal Sisfotek, p.30-37.

Hafidz, Muhammad K., Budiman E. dan Rudiman. (2017). Sistem Informasi Monitoring Nilai Siswa Sdn 017 Anggana, e-ISSN: 2540-7902, Samarinda: Prosiding Seminar Teknologi Informasi FKTI Unmul Vol. 2, No. 1, p.330-335.

Jessup, Leonard M.; Joseph S. Valacich (2008). Information Systems Today (3rd ed.). Pearson Publishing. Glossary p. 416.

Jerry Gao; H.-S. J. Tsao; Ye Wu (2003). Testing and Quality Assurance for Component-based Software. Artech House. p. 170

Jogiyanto, H. (2012). Metodologi Penelitian Sistem Infromasi. Yogyakarta: Andi.

Pressman, Roger, S,. (2012) Rekayasa Perangkat Lunak, Pendekatan Praktisi, Edisi 7, Yogyakarta : Andi.
Palit R. V., Rindengan Y. D. Y., Lumenta A.S.M. (2015). Rancangan Sistem Informasi Keuangan Gereja Berbasis Web Di Jemaat GMIM Bukit Moria Malalayang. E-Journal Teknik Elektro dan Komputer vol. 4 no. 7, ISSN : 2301-8402.

Shodiq M., Satoto K. I. and Kridalukmana R. (2013). SIMBES, Aplikasi Manajemen Beasiswa di Universitas Diponegoro Berbasis Framework Code Igniter dan MySQL.

Setiawan B. (2015). Analisis Dan Pemgembangan Sistem Informasi Monitoring Beasiswa Bidikmisi Fakultas Teknik Universitas Negeri Yogyakarta.

Simanjuntak, E.C., at al. 2010. "Blackbox Testing”. Kompasiana.com. 13 Desember 2010. http://www.kompasiana.com/elisa _grace_heriberty/blackbox-testing_550051c7a333115b735107 db, Aksesed 13 Desember 2019.

Walia E. S. and Gill S.K. (2014). A Framework for Web Based Student Record Management System using PHP. International Journal of Computer Science and Mobile Computing. Vol. 3, Issue. 8, pg.24-33. 